\title{
The Benighted States of America?
}

RB: I recently came across the following item:

In the I920s, a ham producer in Smithfield, Virginia, named Pembroke Decatur 'P. D.' Gwaltney Jr. found a ham in his aging room that, according to his records, had first been cured in I902. Impressed that it was still perfectly edible, he started taking it with him to county fairs, business conventions, and other events to prove the safety and longevity of Smithfield hams. Gwaltney eventually attached a collar and a leash to the piece of meat and started calling it his pet ham. He even insured it, for $\$ 5000$. The pet ham soon made it into newspaper articles around the country; in I 932 the syndicated column "Believe It or Not!" ran a cartoon of the ham and its owner alongside a brief caption: "Although never introduced to cold storage, it remains tender and sweet and fit to eat after 30 years." The petrified-looking ham's current resting place? The Isle of Wight County Museum in Virginia.

Gérard de Nerval was reputed to have walked his pet lobster on a leash in the Palais Royal because, as he said, it "doesn't bark and knows the secrets of the sea." I think we can agree that Monsieur Jambon, a.k.a. P. D. Gwaltney, was less elegantly-but more profoundly-mad. When the French are surreal it's called art. When Americans are surreal it's called life.

JS: Forget Gatsby. The Great Gwaltney knew not only how to bring home the bacon but how to take it out for an entrepreneurial stroll. And only an American would imagine eating his household god and pet ham. I don't really know whether to pour animosity or encomia on Monsieur Jambon for his fully-baked, if not richly

How to cite this book chapter:

Begam, R. and Soderholm, J. 20I5. The Benighted States of America? In: Begam, R. and Soderholm, J. Platonic Occasions: Dialogues on Literature, Art and Culture. Pp. I08-I 22. Stockholm: Stockholm University Press. DOI: http://dx.doi.org/IO.I6993/sup.baa.g. License: CC-BY-NC-ND. 
cured, ingenuity. I do wonder if people in the Benighted States partly inherited their kooky habits from their British forebears, whose talent for eccentricity is world renown. But perhaps Americans have developed their own way of hamming it up, or rather truffling their madness. But are you really complaining about living in a land where the surreal squeals so happily on a daily basis?

RB: Stephen Dedalus described Ireland as the "old sow that eats its own farrow." Presumably Joyce was imagining a porcine Kronos, having cast himself in the role of an avenging Zeus. And what about the U.S., that over-sized behemoth of waggling and waddling flesh? We have so fetishized consumption in this country that it has become a higher calling, a quasi-religion, our own version of Greek arête. We speak of the American consumer in hushed tones of veneration, as though he were a combination of George Washington, Johnny Appleseed and Paul Bunyan. Terms like consumer confidence, consumer spending, consumer safety, consumer protection and consumer price-index are the stuff of White House briefings and Blue Ribbon panels. In the immediate aftermath of 9-I I, President Bush said that the most patriotic thing Americans could do was go shopping. In the eighteenth century, Americans served their country by starving at Valley Forge and standing at Yorktown. In the twentyfirst century, we max out our credit cards at Best Buy and Walmart.

So, yes, I'm complaining. Complaining that in the U.S. we have made a Hormel ham into the New Messiah. Complaining that what in France is a witty poetic conceit becomes in America a witless sales pitch. Surrealism, as the term literally means, is a way of standing above the vagaries of material reality - not a method for plunging into its venalities.

JS: When I listened to Bush's speech about shopping to restore consumer confidence after 9-I I, I was living and teaching in Prague. The next day I went to Charles University and told my students that measuring the vitality of a culture by its ability to feel good about shopping was a sign that America was entering the last phase of its decadence. My bemused students were not impressed. Because their grandparents had been under the heel of first the Germans and then the Soviets, they were trying like hell to forget the past and enjoy 
the boon of capitalism in all its venal vagaries. Cool stuff was a sign of success and wealth, just as Madison Avenue had hoped. They were not particularly appalled by the materialist tumors growing on their quaint streets in the form of KFC, Burger King andhorribile dictu-bars that served Bud Lite (a swill next to which even the most anemic Czech beer is ichor). What I find particularly disgusting is the fact that so many Americans enjoy plenitude yet pretend they are existing in conditions of scarcity, even when the last two generations have mostly wanted for nothing, at least in the middle-class (pagan gods bless Nabokov for calling it the "muddle crass"). Why do so many who have never known want act as if their next Big Mac is their last meal on earth?

So we fiddle with dire prophecies-feckless Cassandras-while Atlanta burns, while America, that still youngish sow, eats its Dixie barbecue, loosens its Bible belt, and waits for a cultural coronary that will spell its doom. To add more fat to this fire, I am ashamed to admit that my adoptive country, Britain, is-as always-following America's lead. Obesity and obedience (the two things your adoptive state of Wisconsin are best at, according to some poll) are the Rosencrantz and Guildenstern of this increasingly sluggish, fatuous, docile country. I still prefer England to the Benighted States, but the infelicitous slurring and blurring of the two cultures give globalization a bad name.

RB: Small "d" democrat that I am, I'm all in favor of giving the vulgus what it wants, and then of mocking the vulgus for wanting the things it does. So if America-or for that matter the Czech Republic-wants to be a pig in a poke that's fine. But it doesn't mean I won't poke the pig every chance I get.

JS: Speaking disparagingly of the vulgus, one is reminded of Nabokov's wistful observation that "There is nothing more exhilarating than philistine vulgarity." Lolita's mother-the fat Hazeepitomizes that vulgarity. She is Emma Bovary without any of the charm or the appealing desperation that makes Emma stuff arsenic into her pretty, torrid mouth. It was you, was it not, who first told me that Lolita is "the mind of Europe meeting the underpants of America"? It is indeed a hilarious meeting but even Nabokov 
said it was not clear who was debauching whom. And, after all, it was the sad clown of Czech literature, Bohumil Hrabal, who called America “The Delighted States.” Benighted \& Delighted. The eternal dialectic?

RB: You have played the aesthetic trump card earlier than I thought you would. Perhaps out of a sense of dialectical desperation? After all, we have no real disagreement. Culturally speaking, America is one vast consumerist wasteland, stretching from sea to shining sea. True, we have the best museums, orchestras, libraries and universities in the world. But our citizenry couldn't care less. For most Americans, Heaven is one big tailgate party, where the home team wins every game, and the beer and hotdogs never stop flowing. In all of history, there has never been a country so powerful and prosperous that was also so contemptuous of the life of the mind. Even among America's educated classes, there is little or no interest in serious art or music. And books are bought-but not read-by a nation content to have Oprah tell them what constitutes great literature.

And yet out of this swamp of cultural waste strange flowers have blossomed. Henry James and William Faulkner specialized in creating ex nibilo, writing sinuous sentences that wrapped themselves around vacuities like a bougainvillea around an invisible trellis. Ezra Pound and T. S. Eliot carried their literary Baedekers across the history and geography of Europe, and then published their travel memoirs as modernist poems. And Wallace Stevens transformed himself from insurance salesman into urbane aesthete, making his uncle into a monocle and discovering comedy in the letter C.

How did these miracles of the imagination occur? America was for its artists what Rouen was for Flaubert. Like the author of Madame Bovary and The Dictionary of Received Ideas, these Americans made a silken mirth out of a sow's ear, an art of consolation out of a culture of desolation. So perhaps you were right when you saluted the Benighted States as the country where surrealism is to be found in every strip mall. Perhaps we should say, along with Nietzsche, that thus only is America justified-as an aesthetic phenomenon. 
JS: Rather, an anaesthetic phenomenon, no?

RB: Ah, but it is the patient who is etherized upon a table. Not the poet.

JS: As Socratic gadflies, poking the unfeeling patient into momentary consciousness, we are somewhere between the poet and the pig, I think. And you know what happened to Socrates. He didn't even get published before they killed him.

RB: Unlike the Youth of Athens, the Youth of America are always already corrupted, so we needn't worry about having to drink hemlock or finding a student who will ghost an Apology for us. Then again, I wonder what one of our former professors-and no mean philosopher himself-would think of this dialogue. In Achieving Our Country, Richard Rorty offers a much more positive view of America than either of us has. If memory serves, you admired the book and were largely in agreement with Rorty.

JS: I remember thinking that Rorty was right about the feckless pretentiousness of the academic Left in our time: that it was shooting blanks to pretend that it had some power in the world of politics. I think you did not admire his smug optimism about America as a Whitman's Sampler of chocolately Songs of Ourselves. Rorty led such a privileged life that he imagined it would be in bad taste to maul the hand that had been so generously feeding him. Many of his tenured, radical colleagues do not have such splendid manners.

RB: Here's one of Rorty's cream-filled bonbons: "Whitman thought that we Americans have the most poetical nature because we are the first thoroughgoing experiment in national self-creation: the first nation-state with nobody but itself to please-not even God. We are the greatest poem because we put ourselves in the place of God: our essence is our existence, and our existence is in the future. Other nations thought of themselves as hymns to the glory of God. We redefine God as our future selves." Care to comment? 
JS: What can I say? Those remarks, or confections, are Rorty's version of the American Dream. It worked for him. The experiment was a wild success. He enjoyed being the "God" of the academic world for a few years. He was a great man and a great poem, but when he died it took the press one week to discover he was dead, whereas Io, oo turned out in the streets of Paris when Sartre went from Being to Nothingness. I think most Americans have the least poetical nature, unless the word "poetical" means something as bland and banal as "dreaming up a career that my father did not have." I take it you have an even less sympathetic reaction to Rorty's audacious hope?

RB: It is depressing to see one of the great philosophers of the last fifty years descend into New Age psycho-babble: "We are the greatest poem because we put ourselves in the place of God ... We redefine God as our future selves." Does this remind you of anyone or anything? How about: "We are the ones we've been waiting for. We are the change that we seek." Not having spent the 2008 election in the U.S., you may not recognize the latter as one of Barack Obama's most celebrated utterances (Chicago, 5 February 2008). It turns out that the Song of the American Left is indeed the "Song of Myself."

And yet I think Rorty was onto something in Achieving Our Country, something that he himself didn't fully appreciate. His paradigmatic heroes were Walt Whitman and John Dewey. Rorty senses that these are quintessentially American characters, and he's right. Whitman stands for the Egotistical Sublime: all self and no other, all future and no past, all individual and no community. The first hippie, he is the Godmother of the Summer of Love, the Protest Movement and Woodstock, which later becomes Hillary's New Ageism-not to mention her Earth Mother lapel pin. Dewey stands for the Will-toTruth: whatever we want to believe we may believe because truth is something we invent. The first postmodern, he is the Godfather of Madison Avenue, Hollywood and Spin City, which eventually give us Al Gore's “invention” of the Internet and Barack's Blackberry.

Of course, for an earlier America-a pre-I968 AmericaWhitman and Dewey meant something different. They represented the limitless possibilities of ingenuity and innovation in 
a country that had freed itself from the past and energetically committed itself to the future. They represented a tough American pragmatism that measured itself in terms of successful outcomes, indifferent to precedent or tradition. These are not bad qualities. Americans have historically been good at solving problems, getting things done, moving forward with dispatch and resolve. But this American grittiness, grounded in a self-interested individualism, epitomizes everything the contemporary Left most abhors about the U.S.

In Achieving Our Country, Rorty tries to reconcile an older America with a newer America, but he does not come to terms with the contradictions. The results are most disappointing.

JS: For you, then, it is too late to seek a newer America? The "heroic" opportunities represented by both transcendentalism and pragmatism have been squandered or transmogrified into materialist swinishness, at once fat and philistine. What then must we do to bring light to the benighted state of the union? Are we doing it now, in this dialogue, or are we merely kvetching because it is always easier to raze a house than to raise one? Or is it better, finally, to move back into the old, dilapidated but still delighted mansion of Europa where the history of ideas is not quite dead until it becomes Islamified into medieval correctness. Then we can talk about the Benighted States of Europe and dream of moving back to the New World.

RB: America will never be the intellectuals' paradise that Thomas Jefferson imagined when he founded his "academical village." In that sense, this is no country for culturally old men. Even urban centers like New York, Chicago and Los Angeles are mausoleums: they offer great museums, orchestras and theatres but it doesn't matter. American life has become so fragmented, anomic and anemic that there is no longer any sense of intellectual or artistic community. Or what little exists is frozen in the amber of cultural institutions, like the American university.

Having said that, I'm a bit (though just a bit) less pessimistic about America's political and economic future. The pre-I968 Whitman and Dewey-the heroic opportunities of transcenden- 
talism and pragmatism-are still alive in this country. To be sure, they are currently in retreat because of the bad economy and the accompanying loss of confidence it has caused. And certainly the current U.S. government is doing everything it can to kill individualism and innovation and replace these values with a bureaucratized and statist model. What will happen in the U.S. over the next few years? I have no idea, but the political choices facing the country are as stark and weighty as they have been since World War II.

As for Rorty, his attempt to reconcile the America of his youth with the America of the twenty-first century is an exercise in nostalgia and wishful thinking. Certainly his efforts were wellmotivated if narrowly ideological. But what Rorty would not or could not recognize is that the American Old Left and the American New Left have virtually nothing in common. The former catered to blue-collar workers and focused on lunch-pail issues. The latter caters to college graduates and focuses on life-style issues. I think Allan Bloom understood what happened in I 968 far better than Richard Rorty.

JS: The latest paradox: the open-mindedness that the Left, old or new, ought to champion, has devolved into the closing of the American mind, which is to say the Death of Mind. From the real world of substantive issues and actual poverty to the surreal world (and Unreal Cities?) of intellectual poverty and bankrupting populism. I wonder what Thomas Jefferson would have made of George Bush and Barack Obama. Can you imagine the three of them in the same room together? The same galaxy? In Jefferson, the fledgling States got the leader they deserved. And now? It's no accident that both of us have stayed frozen in the amber of Academe. At least we can still play with Plato, Shakespeare, Byron, Nietzsche, Conrad, Joyce and Derrida as a way of earning our wages. And who knows if we might actually be forging, in our own modest way, the uncreated conscience of today's youth. How? By suggestively corrupting them-that is, making them think.

RB: Jeffersonian Republicanism has much in common with contemporary Libertarianism. Jefferson favored decentralized govern- 
ment, states' rights, low taxes, reduced spending by Congress and a strict interpretation of the Constitution, which he felt was the best way to protect individual liberties. He would have been horrified by Bush's anti-intellectualism, cultural parochialism and Bible-thumping; but he also would have been horrified by Obama's shameless aggrandizement of power to the federal government. I suspect Jefferson would have hated Bush as a boob and feared Obama as an autocrat.

As for our Socratic mission, I'm skeptical that we accomplish much by "corrupting" the youth of America and England. We may affect a few hundred students in our teaching careers. But a few hundred is nothing when you're talking about hundreds of millions of voters. You and I aren't changing the world. We're entertaining ourselves and the (very) few students who are amused by our jokes.

JS: I suspect you are right, hope you are wrong, and tilt toward the nearest pub as soon as I am finished explaining how and why Shakespeare is a mortal god. But do you really care what happens to America and Americans so long as you can draw your paycheck, spend loads of time in Europe and divert yourself by writing books that a tiny handful of cognoscenti will read before they too return to stardust?

RB: I care about America's destiny to the extent that I care about freedom. America has done more to guarantee freedom than any other country in the world in the last soo years. With mosques popping up in Holland like tulips and Imams running civil courts in England, one wonders how much longer the Enlightenment dream will continue. Perhaps just long enough for you and me to enjoy its benefits before, as you say, we return to stardust.

JS: I read somewhere that there are over I 500 mosques in the U.K. But religion in America is apparently on the rise-again. That rise may be nothing more than increased membership in "the metaphysical club" and therefore decorative and without importance. You claimed at the beginning of this dialogue that 
consumerism was a quasi-religion. What is more culturally baleful and deleterious: Imams or iPads? Or is this a choice of nightmares? Is America more benighted because it still harbors so many avowed Christians or because the shopping mall is replacing the church as a place of Sunday worship? I think that consumerism registers the slow death of religiosity, and therefore I am not too troubled by it and in fact can welcome it. But there is nothing beyond it, nothing to supersede it, nothing for it to grow into.

RB: I distinguish between Christian fundamentalists who annoy me with their beliefs and Islamic jihadists who try to kill me with their bombs. Of course, the role of religion in contemporary America is a matter of concern. Obviously it is depressing to think that an atheist cannot be elected to high office in this country. Jefferson the Unitarian-the eighteenth-century equivalent of a non-believer-wouldn't even be a viable Presidential candidate today.

IPads or Imams? Without doubt, the former. Radical Islam is fundamentally incompatible with Enlightenment, democracy and modernity-values that we both prize. As for choosing between Christians and consumerism, I suppose it depends. Certainly I would rather spend an evening with T. S. Eliot than with the yahoos who charge into Walmart the day after Thanksgiving, as though they are entering the Holiest of Holies. Contemporary Christians may believe in an illusion but that makes them neither pre-modern terrorists nor postmodern barbarians.

In a sense, what we are talking about ultimately comes down to a debate between tradition and modernity. And at the center of that debate is the issue of levity. What happens when we become thoroughly modern, when we liberate ourselves from religion and society, when we float free of history and tradition? At the end of The Unbearable Lightness of Being, Sabina becomes a kitsch artist. Her freedom is translated into empty consumerism. Released from the deadly and deadening gravity of Communism, her identity grows so gossamer-like that it finally dematerializes into a Technicolor puff of air. Something has to ground human beings and all that remains after the Nietzschean transvaluation of all values is aesthetics or the marketplace. And guess which 
one we choose in the U.S.? Since you cited Wilde earlier, I'll cite him now: "Americans know the price of everything and the value of nothing." Better strip malls and McDonalds than the medieval chamber of horrors that radical Islam represents. But the choice of nightmares is not attractive.

JS: Happily, it does not really come down to that choice for us. America will never return to anything resembling Puritanism. It is too infatuated (note the "fat" larding the word) with Walmart, Victoria's Secret and Burger King (the only Monarch Americans will serve) to allow religious wowsers (as Rorty once called them) to thin out their odious, yahoo voraciousness. I don't see anything all that nefarious happening in Britain as far as the rise of radical Islam, although in some parts of England it is illegal to sell piggy banks because they offend a tiny handful of pious Muslims. The Almighty Pig-like the God it has replaced-often roots in mysterious ways. In both our linked cultures, we may indeed speak of the surrealism of everyday life. But the forces that shaped the two cultures (and the common language that divides them) are still so strong that the reign of the pig is amusing, annoying, but hardly alarming. And as much as I inveigh against the horrors of living in a kitsch culture, there is much to add gravity to the Technicolor puffery.

I am anchored by traditions, especially teaching at a school that was founded in 597 A.D. In 55 and 54 B.C., Caesar marched down the street on which I live. In America, I never felt these weighty traditions, save that charmed decade in the I980s when we both capered as graduate students at Jefferson's “academical village." I now begin to see why those years were so rich and lovely. We were immersed in history, tradition and ideas, all of them basically rooted in ancient Greek culture.

But the fact that Jefferson himself, at once a Renaissance and Enlightenment creature, could not today be elected President of the U.S. because of his free-thinking is one of the saddest and most disturbing "developments" in recent American history. Jefferson knew the value of everything and the price of nothing, which makes him the opposite of a citizen of the Benighted States. Of course we felt right at home at the University of Virginia, where Jefferson's presiding spirit still haunts those classical colonnades, 
and where we once strolled, peripatetically, discussing literature and philosophy, wondering how we could keep ourselves from ever having to leave that delighted state of being.

RB: Certainly America is not threatened by a resurgent Puritanism that will turn us into guilt-ridden Arthur Dimmesdales or revenge-seeking Roger Chillingsworths. But our public life is still held hostage by a hypocritical and moralizing Victorianism that occasionally works people and the media into a lather over matters that don't really concern them, as happened several years ago with Tiger Woods, who committed the same crime (heaven forfend!) that earned Hester her scarlet letter.

Of course, once we push through the prim surface of this Victorian posturing, we discover that it's nothing but a shadowbox play. Indeed, in today's America the realm of moral choice has become so medicalized and mediatized-I deliberately use these barbarous neologisms-that no one is any longer responsible for anything he does. The categorical imperative has been replaced by the therapeutic imperative.

First Porcus is crucified. Then Porcus is resurrected. To revert to our opening conceit, it's a surreal combination of piety and exculpation, a morality play in which the morality is all play, something we invoke so that first we can feel good about ourselves, then bad about ourselves, then good about ourselves. Call it media therapy.

When I spoke earlier of a choice of nightmares, I was invoking two large movements in the contemporary world. The weightless, substanceless, simulacral ethos of postmodern America-all image and no reality_-vs. the weighted, freighted and absolutist ethos of radical Islam. Neither is especially attractive, but I'll take bloodless consumerism over bloody hand-chopping any day.

JS: That is a decision that history, ideology and geography have already made for you. You have nothing to endure but the slow, steady decay of tradition, the Fall of the American Empire, the triumph of the Budweiser and brat-obsessed vultures over the well-meaning and meticulous stewards of culture.

In Britain, there is scarcely any difference in that human imbecility and so, from time to time, football maniacs trample one 
another to death in sports arenas, no matter who is winning the stupid game. I think I am running out of things to loathe about human vice and folly, epitomized perhaps in the excesses and hypocrisy of the United States, but certainly amply in evidence in all Western or Westernized cultures.

The good news is-Porcus the Piggod take me now-also the bad news: we will die before our comfortable and fairly rewarding academic way of life goes the way of the Dodo bird. I reckon our uselessness will be complete in about fifty years when books are obsolete and everyone is either medicated into Neverland or solipsized by advances in virtual reality that will, finally, make us forget the lesson of Plato's allegory of the cave. As Alexander Pope darkly observed nearly 300 years ago, "And universal Darkness buries All" as our benighted grandchildren suffer "the Triumph of Dullness" without having a clue that they are dead souls in a dead world, etherized upon a table but with no poet extant to pound any sense into or out of it.

RB: I hate it when, out of dialectical necessity, I am forced into a position of sunny optimism, or-to speak more accuratelyof cloudy ambivalence. Certainly I don't agree with the oftrepeated claim that America is presiding over an empire or that the country's international influence, power and prestige are in inevitable decline. Without doubt, we are headed into what the foreign policy experts call a more multipolar world, one in which Europe, Islam, China and India will play different and larger roles than they have in the past. Nevertheless, the U.S. remains the lone superpower in the world, and we continue to produce more scientific knowledge and to generate more wealth than any other country. It is no accident that each year the Nobel prizes almost all come to this country.

The thrust of my argument has been to separate American culture from American political and economic power. To be sure, museums, theatres, orchestras and universities all require wealth, and one of the reasons we have been successful in producing the former is because we have been successful in producing the latter. Where we have largely failed is in sustaining a public intellectual culture, in constructing a forum where our citizenry 
might see the relations that exist among art, music, literature, philosophy and politics, and then understand how these relations define who we are and what we desire, how they condition our sense of a communal arête. Jefferson imagined America as a loose confederation of Greek city-states in which citizenphilosophers would construct a culture founded on the Good and the Beautiful. His ideas were not all that different, mutatis mutandis, from the notion of Enlightenment set forth by Kant, whose three Critiques are a coordinated attempt to synthesize Knowledge, Morality and Art. Alas, this utopian vision has not and will not be achieved.

As for your wonderfully Byronic vision of Darkness fifty years hence, I can only say "perhaps." Porcus knows that if the current trend lines continue, legitimate library books will soon be as obsolete as blacksmiths and buggy whips. My one and only hope for the future comes from some of the young people I teach. I sat in a Madison pub until $\mathrm{I}: 30$ this morning drinking and talking with one of my former students about Lawrence Durrell, Marcel Proust, William Faulkner, Vladimir Nabokov, Roberto Bolaño, and the Iliad and Odyssey. Who says the Platonic symposium is dead? For that matter, that you and I are both generously supported by our respective polities so that we can sit around writing dialogues complaining about those polities suggests that a certain Greek/Enlightenment ideal lives on in the U.S. and the U.K.

The very real benefits we derive from the great Anglo-American tradition of liberalism and tolerance in no sense diminishes the absurdities, vulgarities and stupidities that we have recorded with such relish and delight in these pages. But perhaps your students at Charles University come closer to getting the sometimes Benighted, sometimes Delighted States of America right. Perhaps, to reanimate our favorite metaphor, we whinging academics are the pampered pigs we have been stigmatizing. Perhaps we should be a little more grateful to a culture that enables us to loll about in the mud, even as we build our castles in the sky.

JS: You may recall seeing these words on a daily basis in the I980s, as we entered Old Cabell Hall, first to take and then to teach lessons: "We are not afraid to follow truth wherever it may 
lead, nor to tolerate any error so long as reason is left free to combat it." Those are the words of Thomas Jefferson to William Roscoe in 1820 , and I remember being proud to be at an institution that was founded by someone so enlightened, courageous and wise. I think certain sad truths about contemporary American decadence and folly have rightly led us to discharge our Swiftian spleen in this dialogue, and I have no regrets about our treatment of the fatuous errors that attend a culture of pampered pigs, even if I am among those swine, or was among them. I am hugely grateful for the time I spent at universities in the States, somewhat sequestered in an academic world where truth, reason and error were words that bristled with meaning. It's the decorative, disgusting "culture" outside the universities that I find so nauseating. There are so few ways of making American citizens at large a bit more intellectual and less obsessed with their mobile phones and automobiles. So I plan to celebrate what deserves celebrating and then whinge and inveigh my way to the grave, recalling Swift's epitaph: "Ubi saeva indignatio / Ulterius cor lacerare nequit."

RB: Swift and Jefferson were both men of the Enlightenment. "Fierce indignation" moved one to write Gulliver's Travels and the other to write The Declaration of Independence. One chose private irony, the other public solidarity. I think where we have ended suggests neither light nor darkness but twilight, harbinger-who can say?-of dusk or dawn. The U.S. is and always has been the best and worst of everything. There is much to excoriate, much to celebrate. What Whitman said of himself we may say of America. She contradicts herself. She is large. She contains multitudes.

JS: Perhaps you're right. After all, only one-hundred miles on Interstate 64 separates the University of Virginia in Charlottesville and The Isle of Wight County Museum in Smithfield that serves both as show-case and mausoleum for Gwaltney's ominouslypampered pig. In any one of the benighted/delighted states of America, we will encounter vast contradictions between higher learning and eating low on the hog. 